DOI: $10.33741 / 0435-1991.41 .10$

\title{
ТОКСИКОЛОГІЧНА ХАРАКТЕРИСТИКА НОВОГО БІЛКОВО-СОЛЬОВОГО ГІПЕРОСМОЛЯРНОГО РОЗЧИНУ
}

\author{
Кондрацький Б. О. ${ }^{1}$, Качмарик Д. Л. ${ }^{1}$, Кондрацький Я. Б. ${ }^{2}$, \\ Патерега І. П. ${ }^{3}$, Кушнір В. І. ${ }^{3}$, Винарчик М. Й. ${ }^{1}$, \\ Панас О. М. ${ }^{1}$, Примак С. В. ${ }^{1}$
}
${ }^{1}$ ДУ «Інститут патології крові та трансфузійної медиџини НАМН України», Львів, Україна
${ }^{2}$ КНП ЛОР «Львівська обласна клінічна лікарня», Львів, Україна
${ }^{3}$ ДНДКІ ветеринарних препаратів та кормових добавок, Львів, Україна

\begin{abstract}
Резюме
Bступ. Розробка нових інфузійних препаратів поліфункиіональної дї $є$ актуальною проблемою сучасної трансфузіологї.
\end{abstract}

Мета - дати токсикологічну характеристику нового білково-сольового інфузійного розчину АХАМ в експерименті на тваринах.

Матеріали і методи. Досліджували інфузійний розчин під лабораторним кодом АХАМ. Препарат містить в якості колоїдної основи донорський альбумін, а також багатоатомний спирт ксилітол, залужнювальний компонент натрію ацетат, антигіпоксант малат та електроліти $\mathrm{Na}^{+}, \mathrm{K}^{+}, \mathrm{Ca}^{++}, \mathrm{Mg}^{++} \mathrm{ma} \mathrm{Cl}^{-}$y збалансованих концентраціях. Осмолярність препарату - 653 мосмоль/л. Дослідження проводили на безпородних білих мишах-самиях та безпородних білих щурах-самиях. Препарати вводили внутрішньоочеревинно в наростаючих дозах. Для клінічної очінки токсичності препарату визначали параметри середньосмертельної дози $\left(L D_{50}\right)$ для нативного препарату АХАМ та концентрованого y 2 рази розчину АХАM-2N (осмолярність - 1306 момоль/л).

Результати. Дослідження показали, що при внутрішньоочеревинному введенні нативного препарату AXAM визначити $L D_{50}$ для білих мишей та білих щурів виявилось неможливим, оскільки введення препарату у надлишковій дозі $(174,0$ мл/кг маси тіла для мишей та 135,8 мл/кг для щурів) не викликало загибелі тварин. Зміни поведінки тварин та їх реакції на введений препарат свідчили, щзо при подальшому збільшенні об'єму інфузійного розчину загибель тварин може бути викликана не токсичною дією препарату, а його надлишковим гіперволемічним ефектом. При застосуванні концентрованого розчину АХАM-2N було встановлено, щчо $L D_{50}$ y білих мишей становить 132,5 $(123,4 \div 141,6)$ мл/кг маси тіла, щуо в перерахунку з концентрованого розчину на препарат АХАМ становить 265,0 мл/кг. При введенні білим щурам концентрованого розчину АХАМ-2N в дозах 40,9; 49,8 та 65,0 мл/кг загибелі тварин не спостерігалося. Тобто для білих щурів середньосмертельна доза $L D_{50}$ концентрованого розчину $A X A M-2 N$ для білих 
щурів є більшою за 65,0 мл/к2, щзо у перерахунку на нативний препарат АХАМ складає 130 мл/кг маси тіла. При екстраполяиії отриманих результатів на організм людини та відповідних розрахунків можна орієнтовно встановити наступні дози - максимальна добова терапевтична доза препарату АХАМ - 12 15 мл/кг маси тіла, середня добова терапевтична доза - 10 мл/кг маси тіла.

Висновки. Середньосмертельна доза $L D_{50}$ препарату AXAM для білих мишей, розрахована через використання концентрованого розчину АХАM-2N, становить 265,0 мл/к2. Для білих щурів LD Розрахункова максимальна добова терапевтична доза препарату АХАМ для людини становитиме 12-15 мл/кг маси тіла. Середня добова терапевтична доза для людини складатиме 10 мл/кг маси тіла.

Ключові слова: альбумін, гіперосмолярні розчини, білково-сольові інфузійні препарати, токсикологічні дослідження.

Конфлікт інтересів: автори заявляють про відсутність конфлікту інтересів.

Фінансування: дослідження не мало спонсорської підтримки.

\title{
TOXICOLOGICAL CHARACTERISTICS OF NEW PROTEIN-SALT HYPEROSMOLAR SOLUTION
}

\author{
Kondratskyi B. O. ${ }^{1}$, Kachmaryk D. L. ${ }^{1}$, Kondratskyi Ya. B. ${ }^{2}$, Paterega I. P. ${ }^{3}$, \\ Kushnir V. I. ${ }^{3}$, Vynarchyk M. Yo. ${ }^{1}$, Panas O. M. ${ }^{1}$, Prymak S. V. \\ ${ }^{1}$ SI «Institute of Blood Pathology and Transfusion Medicine of NAMS of Ukraine», \\ Lviv, Ukraine \\ ${ }^{2}$ CNE LRC «Lviv Regional Clinical Hospital», Lviv, Ukraine \\ ${ }^{3}$ SCI of Veterinary Medicinal Products and Feed Additives, Lviv, Ukraine
}

\begin{abstract}
Introduction. The development of new infusion drugs with multifunctional action is a problem of modern transfusiology.

The aim is to give a toxicological characterization of a new protein-salt infusion solution AXAM in an animal experiment.

Materials and methods. The infusion solution under the laboratory code AXAM was investigated. The preparation contains donor albumin as a colloidal base, as well as polyhydric alcohol xylitol, alkalizing component sodium acetate, antihypoxant malate, and electrolytes $\mathrm{Na}^{+}, \mathrm{K}^{+}, \mathrm{Ca}^{++}, \mathrm{Mg}^{++}$, and $\mathrm{Cl}^{-}$in balanced concentrations. The osmolarity of the drug is $653 \mathrm{mosmol} / \mathrm{l}$.

The studies were performed on outbred white male mice and outbred white male rats. The drugs were injected intraperitoneally in increasing doses. For clinical assessment of the toxicity of the drug, the parameters of the lethal dose (LD50) for native drug $A X A M$ and a 2-fold concentrated solution of AXAM-2N (osmolarity - $1306 \mathrm{mmol} / \mathrm{l})$ were determined.
\end{abstract}


Results. Studies have shown that intraperitoneal administration of the native drug AXAM to determine the LD50 for white mice and white rats was impossible because the introduction of the drug in an overdose $(174.0 \mathrm{ml} / \mathrm{kg}$ body weight for mice and $135.8 \mathrm{ml} / \mathrm{kg}$ for rats) did not cause the death of animals. Changes in the behavior of the animals and their reaction to the administered drug indicated that with a further increase in the volume of the infusion, the death of the animals may be caused not by the toxic effect of the drug, but by its excessive hypervolemic effect. When using a concentrated solution of AXAM-2N, it was found that the LD50 in white mice is 132.5 (123.4 $\div 141.6) \mathrm{ml} / \mathrm{kg}$ body weight, which in terms of the drug AXAM is $265.0 \mathrm{ml} / \mathrm{kg}$. When administered to white rats concentrated solution of $A X A M-2 N$ in doses of 40.9; 49.8 and $65.0 \mathrm{ml} / \mathrm{kg}$ - animal deaths were not observed. Therefore, for white rats, the average lethal dose LD50 of concentrated AXAM-2N solution for white rats is greater than $65.0 \mathrm{ml} / \mathrm{kg}$, which in terms of the native drug AXAM is $130 \mathrm{ml} / \mathrm{kg}$ body weight. When extrapolating the obtained results to the human body and the corresponding calculations, the following doses can be set approximately - maximum daily therapeutic dose of AXAM - 12-15 $\mathrm{ml} / \mathrm{kg}$ body weight, the average daily therapeutic dose $-10 \mathrm{ml} / \mathrm{kg}$ body weight.

Conclusions. The average lethal dose LD50 of the drug AXAM for white mice, calculated through the use of a concentrated solution AXAM-2N, is $265.0 \mathrm{ml} / \mathrm{kg}$. For white rats, the LD50 of AXAM is greater than $135.8 \mathrm{ml} / \mathrm{kg}$. The estimated maximum daily therapeutic dose of AXAM for humans will be $12-15 \mathrm{ml} / \mathrm{kg}$ body weight. The average daily therapeutic dose for humans will be $10 \mathrm{ml} / \mathrm{kg}$ body weight.

Keywords: albumin, hyperosmolar solutions, protein-salt infusion preparations, toxicological studies.

\section{Вступ}

При деяких патологічних станах застосування синтетичних колоїдів на основі декстранів, желатину, гідроксиетилкрохмалю не дає бажаного ефекту. У таких випадках, як правило, застосовується розчин донорського альбуміну. Зважаючи на велику цінність донорської крові, сучасний етап розвитку медицини потребує раціонального підходу до іï використання, зокрема і до переробки на препарати. За останні 10 років з'явилося багато публікацій стосовно застосування альбуміну в клініці та експерименті [1-8].

Досі доволі часто застосовуються комбіновані колоїдно-гіперосмолярні препарати, які містять 6\% гідроксиетильований крохмал та 7,2\% гіпертонічний розчин $\mathrm{NaCl}$ (наприклад, ГіперХАЕC) [9, 10], або поєднане використання гідроксиетильований крохмал та гіпертонічного розчину $\mathrm{NaCl}$ (наприклад, препарату Hextend та 3\% розчину $\mathrm{NaCl}$ ) [11]. Проте, висока осмолярність гіпертонічних розчинів, яка досягається за рахунок високої концентрації $\mathrm{NaCl}$, призводить до надто великої кількості йонів $\mathrm{Na}^{+}$та $\mathrm{Cl}^{-}$, може призвести до негативних явищ (гіпернатрійємія, метаболічний гіперхлоремічний ацидоз). Це обмежує застосування таких препаратів в клініці. 
Підхід із суміщення позитивних якостей гіперосмолярної кристалоїдної складової з колоїдною основою був використаний при створенні і вивченні колоїдно-гіперосмолярного інфузійного розчину HAES-LX-5\% (зареєстрований в Україні в 2013 році під назвою Гекотон) [12-15], а також білковосольових розчинів Лактопротеїн з сорбітолом $[12,16]$ та ALX-5\% [17].

3 огляду на дані літератури та власний досвід з розроблення інфузійних препаратів, був запропонований новий білково-сольовий гіперосмолярний розчин під лабораторним кодом АХАМ. Препарат містить в якості колоїдної основи донорський альбумін, а також багатоатомний спирт ксилітол, залужнювальний компонент натрію ацетат, антигіпоксант малат, електроліти $\mathrm{Na}^{+}, \mathrm{K}^{+}$, $\mathrm{Ca}^{++}, \mathrm{Mg}^{++} \mathrm{Ta}^{-}$у збалансованих концентраціях. Завдяки складу загальна осмолярність препарату становить 653 мосмоль/л.

Одним з показників, що свідчить про клінічну перспективність нового лікарського засобу, є його токсикологічна характеристика.

Мета. Дослідити токсикологічні властивості нового білково-сольового інфузійного розчину АХАМ в експерименті на тваринах.

\section{Матеріали та методи}

Дослідження проводили на безпородних білих мишах-самцях вагою 26-30 г та безпородних білих щурах-самцях вагою 200-230 г, на яких раніше не проводили жодних випробувань. В дослідні групи входило по 8 білих мишей та по 6 білих щурів. Тварини знаходились на звичайному раціоні харчування, за 24 год до випробування тварини знаходились у приміщенні 3 постійною температурою, за 2 год до зважування і відбору тварин для випробування обмежували доступ до їжі і води. Препарати вводили внутрішньоочеревинно в наростаючих дозах. Спостереження здійснювали протягом 14-ти днів після введення препарату. Критерієм оцінки токсичності були: кількість загиблих тварин, загальний стан, особливості поведінки, інтенсивність та характер рухової активності, частота дихання, стан волосяного та шкірного покриву, відношення до їжі, інші показники, які можуть бути використані для оцінки токсичного ефекту.

Для клінічної оцінки токсичності препарату параметри середньосмертельної дози $\left(\mathrm{LD}_{50}\right)$ препарату для білих мишей та білих щурів при внутрішньоочеревинному введенні розраховували за методом трьох точок Б. М. Штабського (1980) [18].

Експериментальні дослідження на тваринах проводили відповідно до методичних рекомендацій Державного Фармакологічного Центру МОЗ України [19] 3 дотриманням етичних норм проведення експериментальних досліджень згідно 3 «Загальними принципами роботи на тваринах», затвердженими I Національним конгресом з біоетики (Київ, Україна, 2001) та Законом України 
«Про захист тварин від жорстокого поводження» від 26.02.2006 р. та «Свропейської конвенції захисту хребетних тварин, яких використовують 3 експериментальною та іншою науковою метою».

\section{Результати та їх обговорення}

Результати дослідження наведено в таблицях 1-4.

\section{Таблиця 1. Визначення гострої токсичності розчину АХАМ на білих мишах при одноразовому введенні максимально допустимої дози (доза - 45,0 мл/кг маси тіла)}

\begin{tabular}{|c|c|c|c|c|}
\hline $\begin{array}{c}\text { Кількість } \\
\text { мишей, } \\
\text { шт. }\end{array}$ & $\begin{array}{c}\text { Загальна } \\
\text { вага } \\
\text { тварин, } \mathbf{~}\end{array}$ & $\begin{array}{c}\text { Доза на одну } \\
\text { тварину }\end{array}$ & $\begin{array}{c}\text { Загальна } \\
\text { кількість } \\
\text { препарату }\end{array}$ & $\begin{array}{c}\text { Спостереження, } \\
\text { Загинуло/вижило тварин }\end{array}$ \\
\hline 8 & 220 & 1,25 мл & 10,0 мл & $\begin{array}{c}\text { За весь період спостереження } \\
\text { загибелі тварин та симптомів } \\
\text { інтоксикації не відмічено }\end{array}$ \\
\hline
\end{tabular}

Таблиця 2. Визначення гострої токсичності розчину АХАМ на білих мишах при багаторазовому 5-ти кратному дробному введенні кожні 1,5 години (загальна доза - 174,0 мл/кг маси тіла)

\begin{tabular}{|c|c|c|c|c|}
\hline $\begin{array}{c}\text { Кількість } \\
\text { мишей, шт. }\end{array}$ & $\begin{array}{c}\text { Загальна } \\
\text { вага } \\
\text { тварин, г }\end{array}$ & $\begin{array}{c}\text { Доза на одну } \\
\text { тварину }\end{array}$ & $\begin{array}{c}\text { Загальна } \\
\text { кількість } \\
\text { препарату }\end{array}$ & $\begin{array}{c}\text { Спостереження, } \\
\text { Загинуло/вижило тварин }\end{array}$ \\
\hline 8 & 230 & $\begin{array}{c}5,0 \text { мл } \\
(5 \times 1,0 \text { мл })\end{array}$ & 40,0 мл & $\begin{array}{c}\text { Після п'ятого введення миші } \\
\text { Пригнічені, втягують живіт. } \\
\text { Через 1,5 години після останнь- } \\
\text { го введення спостерігається ади- } \\
\text { намія. Через 24 години спостере- } \\
\text { ження загибелі тварин та симп- } \\
\text { томів інтоксикації не відмічено }\end{array}$ \\
\hline
\end{tabular}

Таблиця 3. Визначення гострої токсичності розчину АХАМ на білих щурах при дворазовому введенні максимально допустимої дози (доза - 41 мл/кг маси тіла)

\begin{tabular}{|c|c|c|c|c|}
\hline $\begin{array}{c}\text { Кількість } \\
\text { щурів, } \\
\text { штт. }\end{array}$ & $\begin{array}{c}\text { Загальна } \\
\text { вага } \\
\text { тварин, г }\end{array}$ & $\begin{array}{c}\text { Доза на одну } \\
\text { тварину }\end{array}$ & $\begin{array}{c}\text { Загальна } \\
\text { кількість } \\
\text { препарату }\end{array}$ & $\begin{array}{c}\text { Спостереження, } \\
\text { Загинуло/вижило тварин }\end{array}$ \\
\hline 6 & 1320 & $\begin{array}{c}9,0 \text { мл } \\
(2 \times 4,5 \text { мл) }\end{array}$ & 54,0 мл & $\begin{array}{c}\text { За весь період спостереження } \\
\text { загибелі тварин та симптомів } \\
\text { інтоксикації не відмічено }\end{array}$ \\
\hline
\end{tabular}


Таблиця 4. Визначення гострої токсичності розчину АХАМ на білих щурах при багаторазовому 6-ти кратному дробному введенні кожні 1,5 години (загальна доза - 135,8 мл/кг маси тіла)

\begin{tabular}{|c|c|c|c|c|}
\hline $\begin{array}{c}\text { Кількість } \\
\text { щурів, } \\
\text { шт. }\end{array}$ & $\begin{array}{c}\text { Загальна } \\
\text { вага } \\
\text { тварин, г }\end{array}$ & $\begin{array}{c}\text { Доза на одну } \\
\text { тварину }\end{array}$ & $\begin{array}{c}\text { Загальна } \\
\text { кількість } \\
\text { препарату }\end{array}$ & $\begin{array}{c}\text { Спостереження, } \\
\text { Загинуло/вижило тварин }\end{array}$ \\
\hline 6 & 1325 & $\begin{array}{c}30,0 \text { мл } \\
(6 \times 5,0 \text { мл) }\end{array}$ & 144,0 мл & $\begin{array}{c}\text { Після третього введення тварини } \\
\text { малорухливі. Перед та після } \\
\text { П'ятого та шостого введення } \\
\text { щурі пригнічені, втягують живіт, } \\
\text { спостерігається сильне і постійне } \\
\text { сечовиділення. Через 24 години } \\
\text { загибелі тварин та симптомів } \\
\text { інтоксикації не відмічено }\end{array}$ \\
\hline
\end{tabular}

У процесі проведення експерименту загибелі тварин не спостерігалося в жодній 3 груп. Визначити $\mathrm{LD}_{50}$ для АХАМ при внутрішньоочеревинному введенні білим мишам та білим щурам виявилось неможливим, оскільки введення препарату у надлишковій дозі (174,0 мл/кг маси тіла для мишей та 135,8 мл/кг для щурів) не викликало загибелі тварин. Зміни поведінки тварин та їх реакції на введений препарат свідчать, що при подальшому збільшенні об’єму інфузійного розчину загибель тварин може бути викликана не токсичною дією препарату, а його надлишковим гіперволемічним ефектом. Тому збільшення об'єму введеного інфузійного розчину не допускали.

У зв'язку 3 виявленою низькою токсичністю розробленого препарату АХАМ та неможливістю збільшення об'ємів введеної рідини [19], для подальших досліджень використовували спеціально виготовлений препарат під лабораторним кодом AXAM-2N, який містив всі компоненти у подвійній концентрації. Осмолярність цього розчину складала 1306 мосмоль/л.

Результати введення концентрованого препарату АХАМ-2N наведено в таблицях 5-6.

Проведені токсикологічні дослідження показали, що після відповідного розрахунку за методом Б.М.Штабського, середньосмертельна доза $\mathrm{LD}_{50}$ для концентрованого розчину $\mathrm{AXAM-2N}$ у білих мишей становить $132,5(123,4 \div 141,6)$ мл/кг маси тіла. В перерахунку з концентрованого у 2 рази розчину на розроблений препарат $\mathrm{AXAM} \mathrm{LD}_{50}$ для білих мишей становить 265,0 мл/кг. 
Таблиця 5. Визначення гострої токсичності розчину АХАМ-2N на білих мишах при багаторазовому дробному введенні кожні 1,5 години

\begin{tabular}{|c|c|c|c|c|}
\hline $\begin{array}{c}\text { Кількість } \\
\text { мишей, } \\
\text { шт. } \\
\end{array}$ & $\begin{array}{c}\text { Загальна } \\
\text { вага } \\
\text { тварин, г }\end{array}$ & $\begin{array}{l}\text { Доза на одну } \\
\text { тварину }\end{array}$ & $\begin{array}{c}\text { Загальна } \\
\text { кількість } \\
\text { препарату }\end{array}$ & $\begin{array}{c}\text { Спостереження, } \\
\text { Загинуло/вижило тварин }\end{array}$ \\
\hline \multicolumn{5}{|c|}{ Доза 44,4 мл/кг } \\
\hline 8 & 225 & 1,25 мл & 10,0 мл & $\begin{array}{c}0 / 8 \\
\text { Через } 2 \text { години після введення } \\
\text { тварини пригнічені, в’ялі. Надалі } \\
\text { за весь період спостереження } \\
\text { загибелі тварин та симптомів } \\
\text { інтоксикації не відмічено }\end{array}$ \\
\hline \multicolumn{5}{|c|}{ Доза 59,1 мл/кг } \\
\hline 8 & 230 & $\begin{array}{c}1,7 \text { мл } \\
(2 \times 0,85 \\
\text { мл) }\end{array}$ & 13,6 мл & $\begin{array}{c}0 / 8 \\
\text { Після другого введення } 2 \text { тва- } \\
\text { рини дещо адинамічні, } 6 \text { тварин } \\
\text { активні. Надалі загибелі тварин } \\
\text { та симптомів інтоксикації не } \\
\text { відмічено }\end{array}$ \\
\hline \multicolumn{5}{|c|}{ Доза 79,6 мл/кг } \\
\hline 8 & 226 & $\begin{array}{c}2,25 \text { мл } \\
(3 \times 0,75 \\
\text { мл })\end{array}$ & 18,0 мл & $\begin{array}{c}1 / 7 \\
\text { Перед третім введенням } 1 \text { тва- } \\
\text { рина загинула. Після третього } \\
\text { введення } 2 \text { тварини адинамічні, } \\
5 \text { тварин активні. Надалі загибелі } \\
\text { тварин та симптомів інтоксикації } \\
\text { не відмічено } \\
\end{array}$ \\
\hline \multicolumn{5}{|c|}{ Доза 104,0 мл/кг } \\
\hline 8 & 230 & $\begin{array}{c}3,0 \text { мл } \\
(4 \times 0,75 \\
\text { мл })\end{array}$ & 24,0 мл & $\begin{array}{c}2 / 6 \\
\text { Перед третім введенням } 1 \text { твари- } \\
\text { на пригнічена, адинамічна. Перед } \\
\text { четвертим введенням } 2 \text { тварини } \\
\text { дуже пригнічені. Через } 24 \text { години } \\
2 \text { тварини загинули. Решта } \\
\text { активні. } \\
\text { акин }\end{array}$ \\
\hline \multicolumn{5}{|c|}{ Доза 130,0 мл/кг } \\
\hline 8 & 230 & $\begin{array}{c}3,75 \text { мл } \\
(5 \times 0,75 \\
\text { мл) }\end{array}$ & 30,0 мл & $\begin{array}{c}4 / 4 \\
\text { Перед третім введенням } 2 \text { тва- } \\
\text { рини пригнічені, адинамічні. } \\
\text { Перед четвертим та п’ятим } \\
\text { введенням 4 тварини дуже } \\
\text { пригнічені, лежать не рухаючись. } \\
\text { Через 24 години } 4 \text { тварини } \\
\text { загинули. Решта активні. }\end{array}$ \\
\hline
\end{tabular}




\section{Таблиця 6. Визначення гострої токсичності розчину AXAM-2N на білих щурах при багаторазовому дробному введенні кожні 1,5 години}

\begin{tabular}{|c|c|c|c|c|}
\hline $\begin{array}{l}\text { Кількість } \\
\text { щурів, шт }\end{array}$ & $\begin{array}{c}\text { Загальна } \\
\text { вага } \\
\text { тварин, г }\end{array}$ & $\begin{array}{c}\text { Доза на } \\
\text { одну } \\
\text { тварину }\end{array}$ & $\begin{array}{c}\text { Загальна } \\
\text { кількість } \\
\text { препарату }\end{array}$ & $\begin{array}{c}\text { Спостереження, } \\
\text { Загинуло/вижило тварин }\end{array}$ \\
\hline \multicolumn{5}{|c|}{ Доза 40,9 мл/кг } \\
\hline 6 & 1320 & $\begin{array}{c}9,0 \text { мл } \\
(2 \times 4,5 \text { мл) }\end{array}$ & 54,0 мл & $\begin{array}{c}0 / 6 \\
\text { Тварини активні. За весь період } \\
\text { спостереження загибелі тварин } \\
\text { та симптомів інтоксикації не } \\
\text { відмічено } \\
\end{array}$ \\
\hline \multicolumn{5}{|c|}{ Доза 49,8 мл/кг } \\
\hline 6 & 1300 & $\begin{array}{c}10,8 \text { мл } \\
(3 \times 3,6) \text { мл }\end{array}$ & 64,8 мл & $\begin{array}{c}0 / 6 \\
\text { Перед та після третього введення } \\
\text { тварини дещо пригнічені. Надалі } \\
\text { загибелі тварин та симптомів } \\
\text { інтоксикації не відмічено } \\
\end{array}$ \\
\hline \multicolumn{5}{|c|}{ Доза 65,0 мл/кг } \\
\hline 6 & 1330 & $\begin{array}{c}14,4 \text { мл } \\
(4 \times 3,6 \text { мл) }\end{array}$ & 86,4 мл & $\begin{array}{c}0 / 6 \\
\text { Після третього введення тварини } \\
\text { дещо пригнічені. Через 1,5 } \\
\text { години після останнього } \\
\text { введення спостерігається } \\
\text { виражена адинамія. Надалі } \\
\text { загибелі тварин та симптомів } \\
\text { інтоксикації не відмічено }\end{array}$ \\
\hline
\end{tabular}

3 таблиці 6 видно, що при введенні білим щурам концентрованого розчину AXAM-2N в дозах 40,9; 49,8 та 65,0 мл/кг загибелі тварин не спостерігалося. 3 огляду на отримані результати можна стверджувати, що середньосмертельна доза $\mathrm{LD}_{50}$ концентрованого розчину AXAM-2N для білих щурів $є$ більшою за 65,0 мл/кг, що у перерахунку на нативний препарат АХАМ складає 130 мл/кг.

Отже, результати токсикологічного дослідження показали, що при введення білим мишам нативного препарату АХАМ у максимально можливій дозі 174,0 мл/кг не викликало загибелі тварин. При перерахунку середньосмертельної дози $\mathrm{LD}_{50}$ через використання концентрованого розчину $\mathrm{LD}_{50}$ нативного розчину AХАМ становить 265,0 мл/кг.

У білих щурів застосування препарату АХАМ у максимально можливій дозі 135,8 мл/кг не викликало загибелі тварин. При застосування 
концентрованого препарату АХАМ-2N в дозі 65,0 мл/кг загибелі тварин не спостерігалося. В перерахунку на нативний препарат АХАМ ця доза складає 130 мл/кг маси тіла.

Згідно даних літератури [20] середня смертельна доза, зменшена в 1025 разів, є наближеною до терапевтичної дози для людини. 3 огляду на отримані дані, а також дані літератури щодо застосування в клінічній практиці препаратів, подібних за складом до АХАМ, після відповідного обчислення встановлено максимальну добову терапевтичну дозу препарату АХАМ для людини - 12-15 мл/кг маси тіла. Розрахункова середня добова терапевтична доза для людини складає 10 мл/кг маси тіла. Тобто, розроблений препарат AXАМ за своїми токсикологічними характеристиками може бути придатним для застосування у клінічній практиці.

\section{Висновки}

1. Введення білим мишам нативного препарату АХАМ у максимально можливій дозі 174,0 мл/кг не викликало загибелі тварин. Встановлено, що середньосмертельна доза $\mathrm{LD}_{50}$ препарату $\mathrm{AXAM} \mathrm{для} \mathrm{білих} \mathrm{мишей,} \mathrm{роз-}$ рахована через використання концентрованого розчину AXAM-2N, становить 265,0 мл/кг.

2. Для білих щурів $\mathrm{LD}_{50}$ препарату $\mathrm{AXAM} є$ більшою за 135,8 мл/кг, що відповідає максимально можливій дозі, яка не викликала загибелі тварин.

3. Максимальна добова терапевтична доза препарату АХАМ для людини становитиме 12-15 мл/кг маси тіла. Середня добова терапевтична доза для людини складатиме 10 мл/кг маси тіла.

4. Отримані результати експериментальних досліджень $є$ підгрунтям для подальших досліджень розробленого препарату АХАМ.

\section{Література}

1. Rozga J, Piątek T, Małkowski P. Human albumin: old, new, and emerging applications. Ann Transplant. 2013 May 10;18:205-17.

2. Jiang L, Jiang S, Zhang M. Albumin versus Other Fluids for Fluid Resuscitation in Patients with Sepsis: A Meta-Analysis. PLoS One. 2014 Dec 4;9(12): e114666.

3. Patel A, Laffan MA, Waheed U, Brett SJ. Randomised trials of human

\section{References}

1. Rozga J, Piątek T, Małkowski P. Human albumin: old, new, and emerging applications. Ann Transplant. 2013 May 10;18:205-17.

2. Jiang L, Jiang S, Zhang M Albumin versus Other Fluids for Fluid Resuscitation in Patients with Sepsis: A Meta-Analysis. PLoS One. 2014 Dec 4;9(12):e114666.

3. Patel A, Laffan MA, Waheed U, Brett SJ. Randomised trials of hu- 
albumin for adults with sepsis: systematic review and meta-analysis with trial sequential analysis of allcause mortality. BMJ. 2014 Jul 22; 349.

4. Bansch P, Statkevicius S, Bentzer P. Plasma volume expansion with $5 \%$ albumin compared to Ringer's acetate during normal and increased microvascular permeability in the rat. Anesthesiology. 2014;121:817-24.

5. Norberg A, Rooyackers O, Segersvärd R, Wernerman J. Albumin kinetics in patients undergoing major abdominal surgery. PLoS One. 2015; 10: e0136371.

6. Statkevicius S, Bonnevier J, Bark BP, Larsson E, Öberg CM, Kannisto P, et al. The importance of albumin infusion rate for plasma volume expansion following major abdominal surgery. AIR: study protocol for a randomised controlled trial. Trials. 2016; 17:578.

7. von Seth M, Lipcsey M, Engström P, Larsson A, Hillered L, Maripuu E, et al. Rapid bolus administration does not increase the extravasation rate of albumin: a randomized controlled trial in the endotoxemic pig. Shock. 2017;47: 514-519.

8. Statkevicius S, Bonnevier J, Fisher J, Bark BP, Larsson E, Öberg CM, Kannisto P, Tingstedt B, Bentzer P. Albumin infusion rate and plasma volume expansion: a randomized clinical trial in postoperative patients after major surgery. Crit Care. 2019 May 28; 23(1):191.

9. Глумчер ФС, Стрепетов ОВ, Перебийніс МВ. Досвід застосування препарату ГіперХАЕС у клініці інтенсивної терапії. Медицина неотложных состояний. 2013;2(49): 44-7. man albumin for adults with sepsis: systematic review and meta-analysis with trial sequential analysis of allcause mortality. BMJ. 2014 Jul 22; 349.

4. Bansch P, Statkevicius S, Bentzer P. Plasma volume expansion with 5\% albumin compared to Ringer's acetate during normal and increased microvascular permeability in the rat. Anesthesiology. 2014;121:817-24.

5. Norberg A, Rooyackers O, Segersvärd R, Wernerman J. Albumin kinetics in patients undergoing major abdominal surgery. PLoS One. 2015; 10: 0136371 .

6. Statkevicius S, Bonnevier J, Bark BP, Larsson E, Öberg CM, Kannisto P, et al. The importance of albumin infusion rate for plasma volume expansion following major abdominal surgery. AIR: study protocol for a randomised controlled trial. Trials. 2016;17:578.

7. von Seth M, Lipcsey M, Engström P, Larsson A, Hillered L, Maripuu E, et al. Rapid bolus administration does not increase the extravasation rate of albumin: a randomized controlled trial in the endotoxemic pig. Shock. 2017;47: 514-519.

8. Statkevicius S, Bonnevier J, Fisher J, Bark BP, Larsson E, Öberg CM, Kannisto P, Tingstedt B, Bentzer P. Albumin infusion rate and plasma volume expansion: a randomized clinical trial in postoperative patients after major surgery. Crit Care. 2019 May 28;23(1):191.

9. Glumcher FS, Strepetova OV, Perebyinis MV. Experience of HyperHAES in clinic of intensive care. Emergency Medicine. 2013; 2(49): 44-7. 
10. Wurlod VA, Howard J, Francey T, et al. Comparison of the in vitro effects of saline, hypertonic hydroxyethyl starch, hypertonic saline, and two forms of hydroxyethyl starch on whole blood coagulation and platelet function in dogs. J. Vet. Emerg. Crit. Care (San Antonio). 2015;2:1431-44.

11. Duchesne JC, Guidry C, Hoffman JR, Park TS, Bock J, Lawson S, et al. Low-volume resuscitation for severe intraoperative hemorrhage: a step in the right direction. Am Surg. 2012 Sep;78(9):936-41.

12. Семененко ОМ, Яковлева ОО, Семененко CI. Порівняльна оцінка терапевтичного ефекту розчинів HAES-LX-5\% та лактопротеїну 3 сорбітолом в умовах опікової хвороби за динамікою показників біоенергетичних процесів у нирках. Клінічна та експериментальна патологія. 2015;XIV,2(52):180-4.

13. Очеретнюк АО. Вплив гіперосмолярного колоїдного розчину HAESLX 5\% на динаміку змін рівня ендогенної інтоксикації та запалення в організмі щурів у гострому періоді опікової хвороби. Клінічна фармація. 2015;19(4):58-61.

14. Макарова ОI, Чайковський ЮБ. Особливості ультраструктурних змін в респіраторному відділі легень щурів у віддалений період після термічної травми за умов іiі корекції колоїдно-гіперосмолярним інфузійним розчином HAES-LX5\%. Світ медицини та біології. 2014;4(46): 115-20.

15. Semenenko A, Kondratsky B, Hrebtiy G, Malyk S, Hinhuliak M, Bodnar R, Hinhuliak A, Zheliba L, et
10. Wurlod VA, Howard J, Francey T, et al. Comparison of the in vitro effects of saline, hypertonic hydroxyethyl starch, hypertonic saline, and two forms of hydroxyethyl starch on whole blood coagulation and platelet function in dogs. J. Vet. Emerg. Crit. Care (San Antonio). 2015;2:143144.

11. Duchesne JC, Guidry C, Hoffman JR, Park TS, Bock J, Lawson $\mathrm{S}$, et al. Low-volume resuscitation for severe intraoperative hemorrhage: a step in the right direction. Am Surg. 2012 Sep;78(9):936-41.

12. Semenenko OM, Yakovleva OO, Semenenko SI. Comparative evaluation of the therapeutic effect of solutions of NAES-LX-5\% and Lactoprotein with sorbitol in conditions of burn disease according to the dynamics of indicators of bioenergetic processes in the kidneys. Clinical and experimental pathology. 2015; XIV, 2(52):180-4.

13. Ocheretniuk AO. The effect of HAESLX 5\% hyperosmolar colloid solution on dynamics of changes in the level of endogenous intoxication and inflammation in the rat's organism in the acute period of burn disease. Clinical Pharmacy. 2015; 19(4):58-61.

14. Makarova OI, Tchaikovsky AB. Features of ultrastructural changes in the respiratory part of the lungs of rats in the long-term period after thermal injury under conditions of its correction with colloid-hyperosmolar infusion solutions HAES-LX-5\%. The world of medicine and biology. 2014;4(46):115-20.

15. Semenenko A, Kondratsky B, Hrebtiy G, Malyk S, Hinhuliak M, Bodnar R, Hinhuliak A, Zheliba L, et al. 
al. Correction of neurological deficiency in patients with acute ischemic stroke by application of different qualitative composition of infusion solutions. Wiadomości Lekarskie. 2019;72(4): 543-7.

16. Новосад АБ, Кондрацький БО, Новосад АМ, Дутка РЯ, Ошуркевич ЛЮ, Новак ВЛ. Застосування багатокомпонентного препарату лактопротеїн з сорбітолом у хворих на хронічний гепатит алкогольної етіології. Український хіміотерапевтичний журнал. 2008;1-2(22):262-65

17. Кондрацький БО, Качмарик ДЛ, Панас ОМ, Винарчик МЙ, Кондрацький ЯБ, Новак ВЛ. Комплексний білково-сольовий гіперосмолярний інфузійний розчин. Пат. 123110, Україна, МПК А61К 9/08, А61К 47/36. Заявник та власник Державна установа «Інститут патології крові та трансфузійної медицини НАМН України». № a201810706; заявл. 29.10.2018, опубл. 17.02.2021, бюл. № 7, 2021.

18. Нечипоренко ОЛ, Улько ЛГ, Фотіна ГА. Визначення параметрів гострої токсичності нового дезінфікуючого засобу «Дезсан». Науковий вісник ветеринарної медицини. 2018;1:108-16.

19. Доклінічне вивчення лікарських засобів: методичні рекомендації. Під ред. ОВ Стефанова. Київ: Авіценна. 2001, 528 с.

20. Западнюк ИП, Западнюк ВИ, Захария ЕА, Западнюк БВ. Лабораторные животные. Разведение, содержание, использование в эксперименте. Киев: Вища школа. 1983, $383 \mathrm{c}$.

Стаття надійшла 16.08.2021

Контакти:b.kondr@gmail.com
Correction of neurological deficiency in patients with acute ischemic stroke by application of different qualitative composition of infusion solutions. Wiadomości Lekarskie. 2019;72(4):543-7.

16. Novosad AB, Kondratskyy BO, Novosad AM, Dutka RJa, Oschurkevyshc LJu, Novak VL. Application of multicomponent solution lactoproteinum cum sorbitolo for patients with chronic hepatitis of alcoholic etiology. Ukrainian Chemotherapeutic Journal. 2008;1-2(22):262-65.

17. Kondratskyy BO, Kachmaryk DL, Panas OM, Vynarchyk MYo, Kondratskyy YaB, Novak VL. The complex protein-salt hyperosmolar infusion solution. Pat. 123110, Ukraine, МПК А61К 9/08, А61К 47/36. Applicant and owner PI «The Institute for Blood Pathology and Transfusion Medicine of the Academy of Medical Sciences of Ukraine». Number a2018107060; appl. 29.10.2018; publish. 17.02.2021, bull. № 7, 2021.

18. Nechiporenko AL, Ulko LG, Fotina AA. Determination of parameters of acute toxicity of the new disinfectant «Dezsan». Scientific journal of veterinary medicine. 2018; 1:108-16.

19. Preclinical studies of medications: methodical recommendations. Red. OV Stefanov. Kyiv: Avicena. 2001, $528 \mathrm{p}$.

20. Zapadniuk IP, Zapadniuk VI, Zacharia EA, Zapadniuk BV. Laboratory animals. Breeding, content, use in the experiment. Kiev: Vyshha shkola. 1983, 383 p. 